\title{
"between that world and this": A Reading of Breaking News by Ciaran Carson
}

\author{
Elisabeth Delattre \\ Université d'Artois, Arras, France
}

Copyright (c) 2008 by Elisabeth Delattre. This text may be archived and redistributed both in electronic form and in hard copy, provided that the author and journal are properly cited and no fee is charged for access.

Abstract. Ciaran Carson, in the forty poems that constitute Breaking News - published in 2003 -, has used extraneous documents, i.e. the narration by an Anglo-Irish journalist of some of the best-known 19-th century military campaigns, but also the paintings by Francisco Goya, Théodore Géricault, Edward Hopper, or still the poetry of William Carlos Williams. This paper aims at showing how Carson's poetry is given wider scope and deeper resonance through this uncommonly diverse historical, literary and cultural context. The uncanny coexists with reality or gets substituted for it and poetry becomes the ultimate recourse against the unnameable.

Key words. Poetry, painting, wars, intertextuality, verse.

Resumen. En este trabajo se intenta mostrar cómo Ciaran Carson, en los cuarenta poemas que constituyen Breaking News - publicado en 2003- utiliza documentos tan heterogéneos como, por ejemplo, la narración por parte de un periodista anglo-irlandés de algunas de las más conocidas campañas militares del siglo XIX, los cuadros de Francisco Goya, Théodore Géricault, y Edward Hopper, o incluso la poesía de William Carlos Williams. Lo irreal coexiste con lo real o lo sustituye y la poesía se convierte en el último recurso frente a lo innombrable.

Palabras clave. Poesía, pintura, guerras, intertextualidad, verso.

In an article published in 2003, Gerald Dawe emphasized the originality of Carson's new collection: "there is much to distinguish Breaking News, awarded the Forward Prize last week, from his previous collections. The new book emphasizes a different fragmentary diction [...]. The clutter of Carson's aural and visual Belfast has expanded to embrace a gaggle of $19^{\text {th }}$ century sights and sounds" (Dawe 2003). Indeed, in this major work, Ciaran Carson has chosen to represent the horrors of war, of all the past and present armed conflicts, by means of a war correspondent based on the famous nineteenth Anglo-Irish journalist of the Times, William Howard Russell, to whom the book is dedicated - the past thus serving as a metaphor for the present. This passage from one epoch to another is not done without evoking the Irish genre song called "aisling". The forty poems that constitute Breaking News are characterised by a great variety in their length, from three to sixty-nine lines, plus the long poem, "The Indian Mutiny", whose hundred lines occupy a central place in the book. The thirty-one short poems being devoid of punctuation, rhythm and the visual layout on the paper take on a major importance. The brevity of certain poems, in which one finds the influence of the haiku dear to Carson, is counterbalanced by the more lengthy ones relating the stories - sometimes borrowed verbatim from the journalistic hypotext ${ }^{1}-$ of 
the different battles dating from the time when the British Empire was at its acme. The Crimean War of 1854-55 or the Indian Mutiny of 1857, but also the Franco-Prussian War of 1870 , are then an indirect means of representing the present-day world situation. Significantly, Belfast, the poet's birth city of which certain streets bear the names of those battles, becomes the "Forgotten City", after a poem of the same title by William Carlos Williams. Finally, other parts of the book take their inspiration from paintings by Francisco Goya, Théodore Géricault or Edward Hopper, which are all tragic or diabolical representations of murderous folly or solitude. Indeed, Ciaran Carson has used extraneous documents, alien so to speak to his own poetic writing, so as to apprehend better the surrounding world. Thus the poet introduces a logic that participates in a dynamics that is not geared towards mimesis, paradoxical as it may seem, but towards an uncertainty which not so much deconstructs the referential function as suspends it. Only through language can the poet get reconciled with the, at times, unacceptable nature of his environment, even if poetry is above all a struggle against the "weightiness" ("la pesanteur", Bonnefoy 1990: 293) of language. Indeed, poetic form in Breaking News reflects a multi-layered writing whose most prominent feature is the use of intertext as a way of translating an unreliable or unaccountable reality. This results in a fragmentation both of language and referentiation, a subversive technique.

Carson is constantly in search of poetic means that would make possible a changeable conception of the world rather than express a static vision. This is what he declared in an interview following the publication of his prose work, Shamrock Tea (2001):

There are many ways around things. I know for sure that what you say in French is not the same

1. This term is used here in the sense defined by Gérard Genette: “I thereby mean any relation uniting a B text (which I shall call hypertext to an A pre-text (which I shall of course call hypotext) to which it applies in a way different to a commentary." [“J'entends par là toute relation unissant un texte B (que j'appellerai hypertexte) à un texte antérieur A (que j'appellerai, bien sûr, hypotexte) sur laquelle il se greffe d'une manière qui n'est pas celle du commentaire.”] (Genette 1982 : 12-14) Translation mine. thing as what you say in English, if there are ideas behind what we say, they're not the same in Irish or in Hindustani or whatever. To imagine that something can be said in only one form or language is a mistake, I think. Mind you, once it's said in one way it only speaks that one particular thing. (McKeown 2001)

Carson has adopted styles and voices that might seem contradictory. This mechanism through which the poet can renew himself thanks to his art, is a transfer force which no doubt corresponds to his growing use of translation as a writing technique, which is the case with three recent works: The Alexandrine Plan, The Inferno of Dante Alighieri and The Midnight Court. The page layout is also a form of language, an objectivation of the writing which it makes visible. In Breaking News the poem is disposed on the page in a way which might seem aleatory, but is nevertheless regular. The question is for the poet to find a language able to tell the truth, yet at the same time, and here lies the paradoxical aspect of Carson's poetry, he foregrounds the reflexivity of language and in fact the very nature of poetry, just like in the haiku, which can be seen as the opposite of Cratylian writing, whose aim is to hide the arbitrary character of the signs. To quote Yves Bonnefoy, who has written extensively on poetry, the haiku "seeks to find again the immediate within the language whose very nature is to abolish it right from the start" ("cherche à retrouver l'immédiat au sein de la langue qui par nature abolit, d'entrée de jeu, l'immédiat”; Bonnefoy 1990: 142. Translation mine). The poems in Breaking News have to be both read and seen, as the poet is also a teller. Past and present history are de-multiplied into stories set without seemingly any apparent order, but whose final effect forms a whole within the mind of the reader, who is also a listener to what he or she is reading. In that sense, the text of Breaking News illustrates Yves Bonnefoy's definition according to which the poem is above all a narration; it contains a generally quite simple story: "Each poem, let us notice it first of all, holds within its own depth a narration, a fiction, as simple as they may be sometimes" ("Tout poème, remarquons-le d'abord, recèle en sa profondeur un récit, une fiction, aussi peu complexes soient-ils parfois”; Bonnefoy 1990: 192. Translation mine).

In the first part of Breaking News, the poetic text is divided into unequal albeit parallel 
stanzas, often made up of one or two very brief lines, and most of the time each poem is constituted by just one sentence. The rhyming pattern is used in an original way: when it exists, it can be limited to assonances or be very approximate. Lastly, some words have no respondent. The text is thus fragmented and gives the impression of a frittering away of the world or else of a slow and inexorable degradation - "rust" being a recurring term. In the poem "Breaking", the car about to explode anticipates the disintegration of the letters of the ensign of the Belfast Telegraph in the visà-vis poem entitled "News":

it's
oh
so quiet
you can
almost
hear it rust (Carson 2003:16)

Just like the rhymes, however, the regular verse pattern has not been banished. The suppression of punctuation, contrary to what is often maintained, does not create any uncertainty as regards the regrouping of terms, for it is easily restored upon reading; however, it allows for a certain degree of suppleness in the rhythm and the variations of diction. The impression of a kaleidoscope, of a gyring thus produced corresponds to the poet's interrogations about the world which surrounds him. And this environment is not only the immediate one but is also farther both in space and time, since the poem "Russia" was inspired by the writings of Isaac Babel, a Jewish novelist and playwright who was correspondent of the Red Army's forces during the Russian civil war.

In Breaking News, Carson combines innovation and a renewed use of traditional formulae, the regular rhyme becoming, if not the norm in the second part entitled "The War Correspondent”, at least an essential stylistic aspect, which is where the hypertext becomes distinct from its journalistic hypotext. The technique used by Carson in this second part can be defined as a form of collage, for some passages are borrowed word for word from the journalistic hypotext. The consultation of Carson's sources, i.e. Russell's stories, evinces this stylistic fact. Let us quote two sentences taken up by Carson: "The Turks marched in dense columns, bristling with steel” (Hudson 1995: 52) and "The howling of the inhabitants, the yells of the Turks, the clamour of women, children, dogs, and horses, were appalling" (Hudson 1995: 10). It is above all a question of recycling or recuperating existing materials whose cohabitation within the very text will allow them to be perceived in a new light. Likewise, a dead horse is "recycled" so as to provide a number of useful objects in "Some Uses of a Dead Horse":

the bones give
buttons
snuff-boxes
and knife-handles
the hooves
yield
a beautiful
Prussian blue

the shoes shot (Carson 2003:32)

The Carsonian hypertext is indeed a meeting-place for different stylistic registers, since William Carlos Williams' poem, "The Forgotten City", gives rise to a new poem whose backcloth is the city of Belfast - the main theme in the Northern-Irish poet's work. While in Williams's poem, the weather conditions (a hurricane) had been the main cause of the disturbance, in Carson's the context is quite different: it is the rioting which has caused the pavements to be overturned and the water mains to be broken. We may remember that in Williams's poem, the childnarrator was going back with his mother to a city which he no longer recognized: "When with my mother I was coming down / from the country the day of the hurricane, / trees were across the road and small branches / kept rattling on the roof of the car" (Williams 1976: 140). In Carson's poem, the stress is laid on the transitory, the ephemeral, and the evanescent, despite the insistence on the notion of permanence. The narrative structure establishes a parallelism between several periods of the city's history so as to multiply the connections among them, and this provides a special temporal depth. Carson has often insisted on this notion of interconnectedness, of the link between epochs and events in his work: "I 
believe that the world exists in such a way that everything relates to something else. Or we make it exist in that way, making links all the time, connecting things up, one thing always leading to another" (Brown 2002: 142). In "The Forgotten City", ghostly beings haunt the present. And the city is seen as something mysterious and magical for the cyclist coming back after spending some time in the countryside, far from the noise and agitation of the riots: "I had no idea where I was and promised myself / I would go back some day and study this / grave people" (Carson 2003: 44). If the influence of the myths surrounding the city gives it a special character, there is in Carson's poem a hyper-real construction of language that defies temporality, logic and temporal rationality, in which the uncanny coexists with the banal as in the poetic hypotext: "a strange commonplace” ( Williams 1976: 140).

In Breaking News, writing and painting alternate mutually. As Yves Bonnefoy has shown, the immediacy of the real and the difficulty of transcribing it into words are a reason why some poets have resorted to the medium of painting: "It is a fact, which one can verify easily: the more specifically poets have been looking for the immediate, the more they have interested themselves in the technique of painting - which was in their eyes nothing short of miraculous" (C'est un fait, qu'on vérifie aisément: plus spécifiquement des poètes ont désiré l'immédiat, plus ils se sont intéressés à la technique de la peinture, à leurs yeux en somme miraculeuse”; Bonnefoy 1992: 340. Translation mine). Carson is interested in painting because of his belief in the possibility of transferring energies from one medium to another, as he did in The Twelfth of Never (1998) apropos music and dance. In the short poems in Breaking News, he is in search of a structure of reduced units of perception, but the blanks left between them become musical silences; the recurrence of terms belonging to sound and visual registers that of "blindness" and its opposite, the light or the clarity of sight notably - is significant. That is why the compound past participle "whiteshirted" echoes another past participle, "blindfolded" (Carson 2003: 47) which ends the poem devoted to a painting by Goya, The Third of May, 1814, a painting Seamus Heaney in his poem "Summer 1969" associated with the renewal of sectarian violence in Northern Ireland:
Goya's 'Shootings of the Third of May'

Covered a wall - the thrown-up arms

And spasm of the rebel, the helmeted

And knapsacked military, the efficient

Rake of the fusillade. (Heaney 1998: 140)

The bare syntax and the laconic content of Carson's poem further enhance the solitude and courage of the sentenced man, clad in a white shirt and without a blindfold before the firing-squad. Such a scene becomes emblematic of man's resistance when faced with oppression and repression at any time and in any place. The imperative tense "behold" (Carson 2003: 47) invites the reader to see the painting in his imagination, for intertextuality here is situated on the level of speech and of the relationship with the Other. Indeed, the word, for Carson, also refers to itself and to a multiplicity of non-referential games, for the word, according to Bonnefoy, is "matter, a sound that begets on the level of the sentence a form of the same sound nature, and in this it is rhythm, and besides, right from the start, it is a breath, which uses our breath, which gives it life outside us" ("une matière, [...] un son qui amorce au plan de la phrase une forme de même nature sonore, et en cela même il est rythme, et d'ailleurs d'emblée il a été souffle, qui emploie notre souffle, qui le fait vivre hors de nous"; Bonnefoy 1990: 262. Translation mine). Just like the philosopher for Louis Wittgenstein - a central figure in Carson's prose work Shamrock Tea - the poet cannot think outside language and the limits of the poem (or philosophy). The power of words rests on their problematic capacity for ordering, structuring and syntactically setting up so as to produce a specific rhythm, as Carson declared in a recent interview: "Maybe it's not fashionable to say that technique can stand outside content, but there you are. I think style per se is a thing to aim at" (Brown 2002: 145). The disposition of words on the paper is the result of a combination with infinite potentialities for which the poet has to invent new rules. This partly explains the usage of very diversified stanzas, with sometimes complex rhymes - thus the poem "Balaklava", in which each line of the four quatrains that compose it rhymes with the same line on the next stanza. Such stylistic variety enables the poet to play on diversity, which is precisely that of the surrounding world.

With Carson, language is reality or can embody it, being likewise contradictory and 
unified, and it is insofar as this ambiguity is maintained that the real exists. Indeed, poetry is not "the subversion of the discourse of the law by that of desire, $[\ldots]$ the invention of imaginary worlds, but their destruction, their renewal, their effacement once again. [...] And therefore it is a testimony, a call" ("la subversion du discours de la loi par celui du désir,...l'invention de mondes imaginaires, mais la destruction de ceux-ci, leur recommencement, leur effacement encore... Et c'est donc un témoignage, un appel” ; Bonnefoy 1990 : 328. Translation mine). Imagism advocated the complete erasure of view-point in the poem, which would become a pure "image" immediately transcribed onto the page. As it was the foundation of modernist impersonality, this theory flew in the face of the irreducible nature of the poetic voice. For Carson, as was also the case for Williams, the only remedy to this difficulty is, on the contrary, to emphasize the poet's viewpoint and give the lie to the immediacy of perceptions. That's why the poem “describing” Early Sunday Morning, a work by the American realistic painter Edward Hopper, ends with these lines, full of uncertainty and apprehension before the unknown:

you know
that quiet
when the
washing-machine
stops
shuddering (Carson 2003: 23)

Some echoes of this poetry can be found in Carson's preceding work, The Inferno translated from Dante, all the more so as their composition was contemporary with the translation from the Italian poet. In Breaking News, there is no longer any room left for dialogue nor is any understanding possible, and a rhythm as staccato as that of the helicopter blades then invades the white page in the threeverse poem "Spin Cycle 2" : "gun-gun / earplugs in / blank-blank" (Carson 2003: 40). An excessive reality thus reveals itself in Carson's book, which unsettles representation and fragments it to a point beyond which writing and subject abreact. Paratactic accumulations with abrupt sonorities reveal a chaotic world which only configurations of plosive and whistling sonorities seem to organise - thus the incipit of "Gallipoli", the first section of "The War Correspondent":
Take sheds and stalls from Billingsgate, glittering with scaling-knives and fish, the tumbledown outhouses of English farmers' yards

that reek of dung and straw, and horses cantering the mewsy lanes of Dublin (Carson 2003 : 56)

And we could find many such examples in the book. The poetic narration is built around unacceptable events that are almost unreal by their very concreteness. The poetic writing is part and parcel of its own dynamics, and the reader might be tempted to lose his or her bearings amidst such an avalanche of facts, were it not for an implacable and strict rhythm, which becomes even more apparent when Carson himself reads the poems in public. Carson de-familiarises representation, drives it to its utmost limits, so as to define better the task and the power of words. Life and death coexist or get mixed until they end up in a fascinating and fascinated dispersal of being thus in the seventh and last section of "The War Correspondent": "Hands hanging in the trees / in lieu of fruit, / trunkless legs at their feet" (Carson 2003: 71). Only the chaos and disorder of an accumulation of facts as bloodless as the bodies can still suggest the relentless annihilation of things and beings through the defeat of the codes and modes of representation. The decor turns into a strict accumulation of artificial accessories which the brutality of the situation reduces to some derisory panoply. The humans in Breaking News are thus irresistibly tempted to abandon themselves to their deprivation, to their losses rather. They get undone, are threatened with becoming mere flesh, a degrading ambiguity underlined by war clichés, as in the short poem "War", sometimes quoted by its author in order to symbolise present-day conflicts:

Sergeant Talbot
had his head
swept off
by a
round-shot
yet for half
a furlong
more
the body kept
the saddle


horse and rider

charging on

regardless (Carson 2003: 26)

Language itself breaks up, is given a form of crude incoherence that has no other equivalent than the brutality of a world encapsulated by the pen of the journalist, but also the brush of the painter. Man gets mixed up with animals, seen as victims of the wars, in the same way as Michael Longley paid homage to these innocent creatures in an elegiac form in The Weather in Japan (2000): "For all the horses butchered on the battlefield, / Shell-shocked, tripping up over their intestines, / Drowning in the mud, the best memorial / Is in Homer" (Longley 2000: 29). The horse becomes man's alter ego, their destinies seem intermingled, as is shown in the poem inspired by a painting by the French artist Géricault: "man and horse / deadlocked / raked by light” (Carson 2003: 42). This painting, which dates from 1814, the year preceding the great and murderous battle of Waterloo, was reproduced on the cover of Carson's Breaking News, and can be seen as emblematic or metaphorical of Carson's purpose.

Indeed, descriptions become opaque by dint of apparently accessory details, but their effect is to ramify the text to infinity and close it upon itself. Words, details become accumulated, stratified, like the landscape whose beauty becomes all the more poignant as human beings destroy it under their feet, which is what happens in "Balaklava" : "As the Turkish infantry advanced, their boots creaked / and crushed the springy flowers, and delicate / perfumes wafted into the air beneath the April sky" (Carson 2003: 63). Like the bodies, representation gets unravelled, spreads out, as a sort of analogical and figured image, which is metaphorical of referential space as well as the work of memory. The concretions of language become such that the main clause verb is missing in the poem "Sedan" (Carson 2003: 70-71). The writing remains linked to a form of precariousness which is reinforced by the strangeness of some words ("Turcos", "Zouaves”). The narration turns back on itself, for representation often assumes a deceiving appearance; such is the remark of the narrator in "Dvno", who is horror-struck by his discovery: "One day, down by the sea-shore,/ I scraped my name with a stick / on the sand, and discovered / the rotting face of a corpse"
(Carson 2003: 62).

Against this deconstruction of space and of meaning, the human being can only, at most, once more, abreact. Language abandons itself, like bodies, to an organic exudation. Negative factual objects, such as a missing head or an absent door, turn out to be "now empty shells" (Carson 2003: 66), signs of dispersal, of dislocation that break up the referent as well as the expression. The uncanny gets substituted for the normality of the surrounding nature: "Strange to hear them sing about the bushes", wonders the narrator at the battle of Tchernaya (Carson 2003:68). Space becomes composite, incoherent, and experiences its own dismemberment, as in the poem "Siege":

the road
to Sevastopol
is paved
with round-shot
the road
from Sevastopol
with boots
that lack feet (Carson 2003:50)

There only remain "bits and pieces" (Carson 2003: 24) that appear as cruel and atrociously derisory traces of a faceless violence. One finds only scattered elements, torn out from their emplacement, their organic places. Space and the human body are denied their integrity, after the sacking of Kertch by the French army, such is the sight the English soldiers had before them: "every cupboard / with a pair of red breeches / sticking out of it, and a blue / coat inside of it" (Carson 2003: 65).

The present tense used in most of the short poems functions as a thematic tool, for it is that of a bruised memory, like a wound that will not heal. To the distancing of the preterit in the second part devoted to the 19th century, is opposed the clarity of the present tense that makes it possible, in some way, to accommodate more easily, to apprehend better the reality of things, while, paradoxically, the contours of yesterday and today get more and more blurred in the first part. The imperative tense in "Gallipoli" - the first poem of the second part - marks a break in the course of the narration. The present of narration, theoretically unacceptable in English, then becomes the primordial tense in the short poems, in the midst of which a heretofore inopportune preterite in the very long poem 
"The Indian Mutiny" slides in, or rather strays in: "I had to rub my eyes / before this vision / vaster and more beautiful than Paris" (Carson 2003: 28). Discursive norms, like temporal perspectives, are doubly reversed, since they are swept away, but also returned to some atemporal tense, that of poetic narration, such as it is transmitted to the reader over the years:

$$
\begin{aligned}
& \text { - twelve inches } \\
& \text { lower and I'd not } \\
& \text { be here to write } \\
& \text { nor would you read } \\
& \text { this news of how }
\end{aligned}
$$

\section{we freed Lucknow. (Carson 2003: 31)}

Carson's poetry foregrounds the complex relationships between mimesis and language, notably the fact that words refer above all to the inner play of the signifiers prior to functioning in a referential system. Without any temporal indication which might contribute to establishing the moment of enunciation, the text tends to become disarrayed in the short poems. The poetic narration is then in abeyance, without any anchorage, moving along by the sheer impulse of its own deviant power. Only humour can at times redeem it: "he opened / the Bible / to reveal / the bullet / stopped / at Revelation” (Carson 2003: 33). To be a poet, according to Jacques Derrida, "is to be able to leave the narration. To let it run on its own, and this it can only do in writing" ("c'est savoir laisser la parole. La laisser parler toute seule, ce qu'elle ne peut faire que dans l'écrit"; Derrida 1967: 106. Translation mine). The monologue of the poet is just a derisory soliloquy defying solitude, oblivion and death, the narrator telling about his inability to do more - thus his conclusion to the poem "Gallipoli": "I have not even begun to describe Gallipoli” (Carson 2003: 58) - or else histrionics is reduced to a pathetic chimera, expressed by the nocturnal walker on the streets of a ruined Belfast:
and
it is
as much
as I can do
to save
even one

from oblivion (Carson 2003 : 51-52)
In "The War Correspondent", the horror of the war, as well as the activities of the occupation armies, are designed in absentia through the use of bathetic references that appear empty by dint of being used again and again and are most of the time borrowed from the journalistic hypotext. At odds with any identifiable reference point, the text becomes as it were uprooted, almost utopian, torn from any precise location. The neutral and mute language seems to have lost any grip on reality, while the anonymous soldier feels a prisoner in the poem "Trap": "I don't / read you / what the / over” (Carson 2003:15). There only remain syntagms bereft of any substance, bloodless envelopes of a ghostly real, as in the poem "Shop Fronts":

cheek by jowl

chemist

tobacconist

Wilkinson Sword

razor-blades

Warhorse

plug (Carson 2003: 21)

An impression of abeyance arises from the text whose referential location is uncertain, even if dates punctuate here and there the poetic discourse. Dispersed along the poetic narration, such notations paradoxically contribute to dissolve the referential link, to make it more precarious. A veil envelops the text, breaks up its transparency, makes it opaque ; the dream of Eden compared to an Irish garden is immediately replaced by an unnameable reality in the poem "Dvno": "But at night a fog descends, / as these woods breed miasmas, / and slithering through the brush / are snakes thick as a man's arm”(Carson 2003: 61). According to what Derrida says about writing, "it is an exit out of the world, towards a place which is neither a void nor another world, neither a utopia nor an alibi" ("il s'agit d'une sortie hors du monde, vers un lieu qui n'est ni un non-lieu ni un autre monde, ni une utopie ni un alibi”; Derrida 1967: 17. Translation mine). And there is no solution to such a collapse other than in a soundless, incongruous space where fragments of beauty persist, which is where the sequence of poems ends:

even the bomb-shelters

ransacked, though in one dug-out

I found a music-book 
with a woman's name

in it, and a canary bird,

and a vase of wild flowers. (Carson 2003: 72)

Sure enough, to take up Bonnefoy's terms, it is impossible to get rid of words: "we are devoted to the words and have made of each of them the continued abolition of the primary presence. The spoken word is then a loss, an exile" ("nous sommes voués aux mots et devons faire de chacun d'eux l'abolition continuée de la présence première. La parole, en cela, est une perte, un exil”; Bonnefoy 1990: 241. Translation mine). Ciaran Carson's poetry is confronted with the symbolic nature of language, which is both its function of division and of connexion. Language here appears as a tool that connects the human to the world but also enables him to escape his own condition. That is why Carson's poetry is a poetics of loxos, being dominated by the ephemeral and the tangential that characterise the world where he lives, and thereby the things of beauty he admires, but of which he knows the provisory and untenable nature, as in "Wake", a poem which is emblematic of Carson's vision of the world and of his poetry:
then in
the lull
a blackbird
whistled in
a chink
of light
between
that world
and this (Carson 2003: 53)

\section{Works Cited:}

Bonnefoy, Yves. 1990. Entretiens sur la poésie (1972-1990). Paris: Mercure de France. 1992 (1977). Le Nuage rouge. Essais sur la poétique. Ed. revue et corrigée. Paris: Mercure de France.

Brown, John (ed.). 2002. In the Chair. Interviews with Poets from Northern Ireland. Cliffs of Mohair: Salmon Publishing.

Carson, Ciaran. 1998. The Alexandrine Plan. Versions of sonnets by Baudelaire, Mallarmé, and Rimbaud. Loughcrew: Gallery Press. . 1998. The Twelfth of Never. Loughcrew: Gallery Press.

. 2001. The Inferno of Dante Alighieri. A new translation. London: Granta Books. . 2001. Shamrock Tea. London: Granta Books. 2003. Breaking News. Loughcrew: Gallery Press.

2005. The Midnight Court. A new translation of 'Cúirt an Mheán Oíche' by Brian Merriman. Loughcrew: Gallery Press.

Dawe, Gerald. 2003. "Mapping the territory”. The Guardian. Saturday October 18th.

Derrida, Jacques. 1967. L'Ecriture et la différence. Paris: Seuil.

Genette, Gérard. 1982. Palimpsestes. Paris: Seuil.

Heaney, Seamus. 1998. Opened Ground. Poems 1966-1998. London: Faber \& Faber.

Hudson, Roger (ed.). 1995. William Russell; special correspondent to the Times. London: The Folio Society.

Longley, Michael. 2000. The Weather in Japan. London: Cape.

McKeown, John. 2001. "Plotting the swirling kaleidoscope", The Irish Times. Monday April 2. http://www.ireland.com.

Williams, William Carlos. 1976. Selected Poems. Penguin Books: Harmondsworth. 